\title{
Experimental Study of the Influence of a Combination of Operating Parameters of a Mobile Lift on Oscillatory Processes Occurring After Locking the Working Platform
}

\author{
Igor Kyrychenko $^{1 *}$, Oleksandr Reznikov ${ }^{1}$, Dmytro Klets ${ }^{1}$, Anton Kholodov ${ }^{1}$ \\ ${ }^{1}$ Mechanical engineering faculty, Kharkiv National Automobile and Highway University, Kharkiv (Ukraine)
}

The article provides a detailed analysis of the influence of the combination of performance indicators of mobile lifts with working platforms (MLWP) at the stage of stopping and the process of vibration damping after stopping the working platform.

On the basis of the results of experimental research and processing of the obtained data, an analysis was made of the influence of the angles of inclination of the upper and lower sections of the boom and the mass of the load in the working platform on the maximum amplitude of oscillations of accelerations when the working platform is locked, the period of oscillations and the time of their damping.

As a result of the analysis, the spectrum of the response surfaces of the maximum amplitude of acceleration oscillations when the working platform is locked, the period of oscillations and the time of their damping from the working mass and the angles of inclination of the lower and upper boom sections was obtained, on the basis of which it can be concluded that the value of the maximum amplitude of acceleration oscillations in the locking time of the working platform is most influenced by the mass of the load in the working platform.

Keywords: Mobile lift, Working platform, Locking, Vibrations, Operational performance, Response surface.

\section{INTRODUCTION}

During the MLWP operation, oscillatory processes are observed that occur after the working platform is locked. This operating mode is emergency and is observed in the event of a break in the hydraulic drive of the working equipment or an abrupt stop of the working platform.

There is a need for a detailed study of the process of locking the working platform of the MLWP and identifying the performance of the machine and options for their combination, most significantly affect the maximum amplitude of oscillations of accelerations when locking the working platform, the period of oscillations and the time of their damping.

\section{ANALYSIS OF RECENT RESEARCH AND PUBLICATIONS}

In recent years, a large number of studies have appeared aimed at studying the processes observed in MPP during operation. In the works [1-2], the issues of theoretical development of control systems for the movement of the working platform of hydraulic lifters are considered, in addition, a large number of studies are devoted to the study of processes occurring in the volumetric hydraulic drive of machines [3-4]. The analysis and study of the MLWP load modes are given in [5-6], however, there is currently no comprehensive study regarding the appearance of oscillatory modes during operation and stopping of the machine.

In [7], the issues of determining the parameters of motion of an auto-hydraulic lift with a rotary joint are considered, however, insufficient attention is paid to the experimental study of the process of locking the working platform in modern works.
The purpose of the article is to study the influence of the combination of the operating parameters of a mobile lift on the maximum amplitude, period and time of damping of oscillations of the working platform after its locking. To achieve this goal, the following tasks have been identified:

- to carry out a statistical analysis of the experimental data and, on the basis of the data obtained, to construct the response surfaces of the maximum amplitude, period and time of damping of oscillations of the working platform after it is locked from the operational indicators of the working process;

- to determine the degree of influence of the combination of operational parameters of the MP on the oscillatory processes that occur after the working platform is locked;

- based on the data obtained, draw conclusions and make recommendations.

\section{PRESENTATION OF THE MAIN MATERIAL}

For a more detailed study of the locking stage and the process of vibration damping after stopping the working platform, a statistical analysis of the vibrations of the working platform after it stopped was carried out. The analysis was carried out according to the maximum amplitude of the oscillations of the accelerations when the working platform was locked, the period of oscillations and the time of their decay, depending on the performance indicators. As a result, the response surfaces of the maximum amplitude of acceleration oscillations at locking of the working platform, the period of oscillations and the time of their damping from the working mass and the angles of inclination of the lower and upper sections of the boom were obtained. 


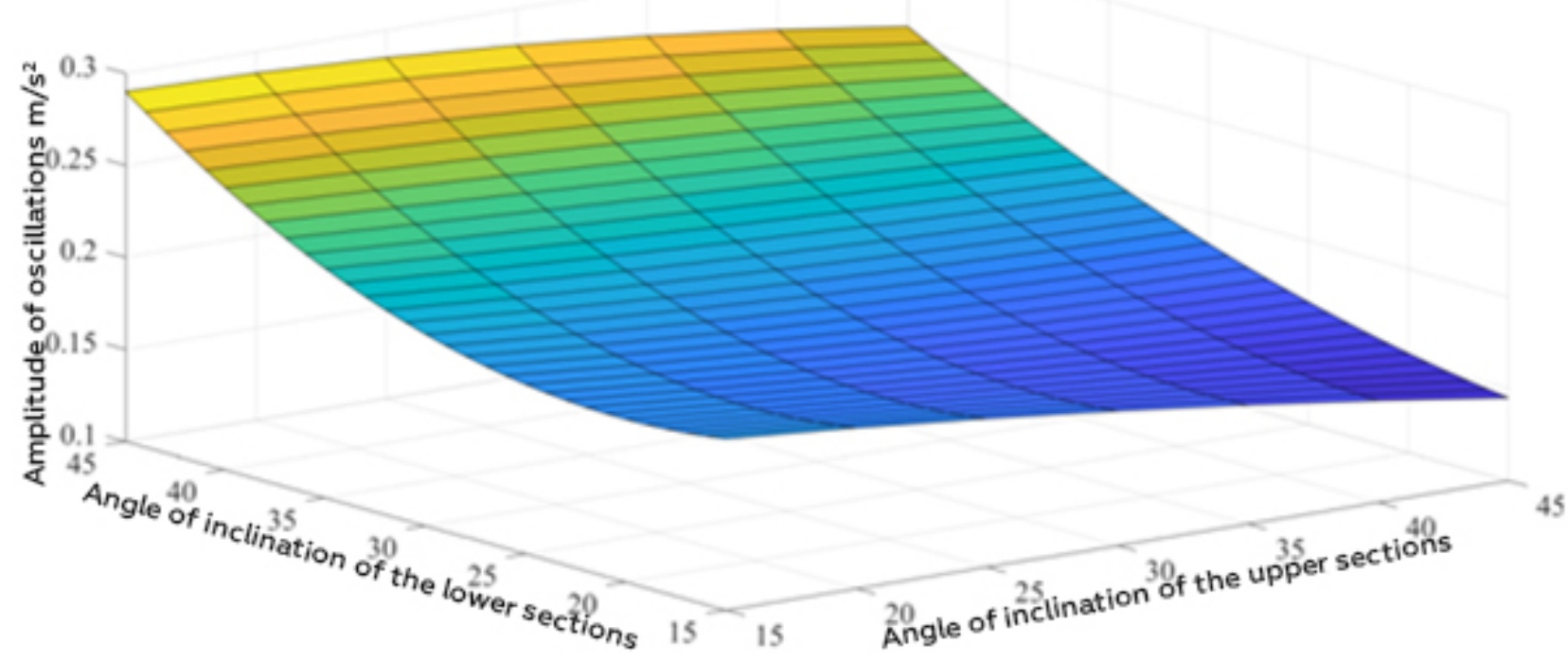

$a$
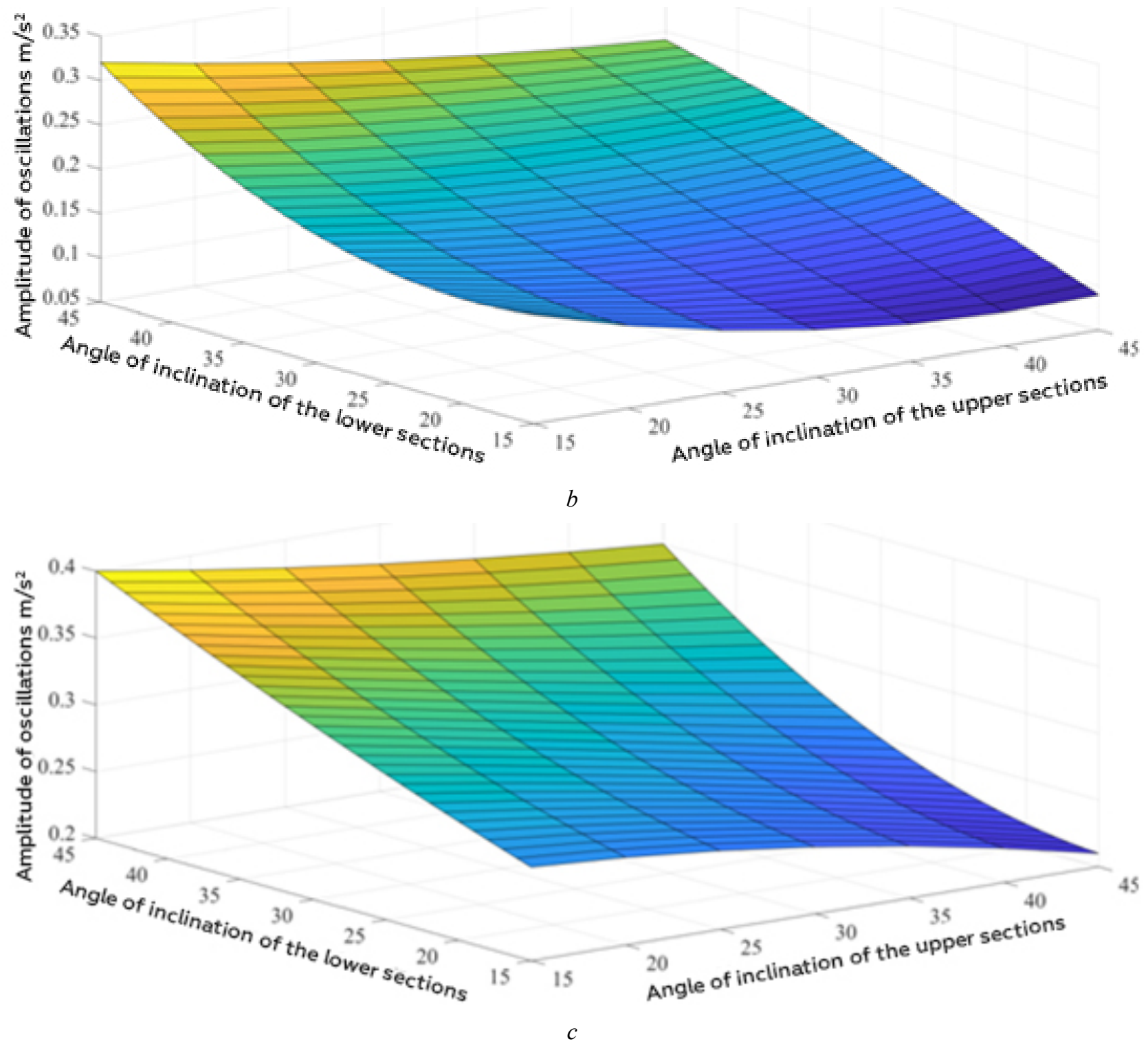

Figure 1. Response surface of the maximum amplitude of oscillations of the working platform from the angles of inclination of the lower and upper sections of the boom: $a$ - with a load mass of $35 \mathrm{~kg} \mathrm{~b}$-with a load mass of $70 \mathrm{~kg} \mathrm{c}$ - with a load mass of $105 \mathrm{~kg}$ 

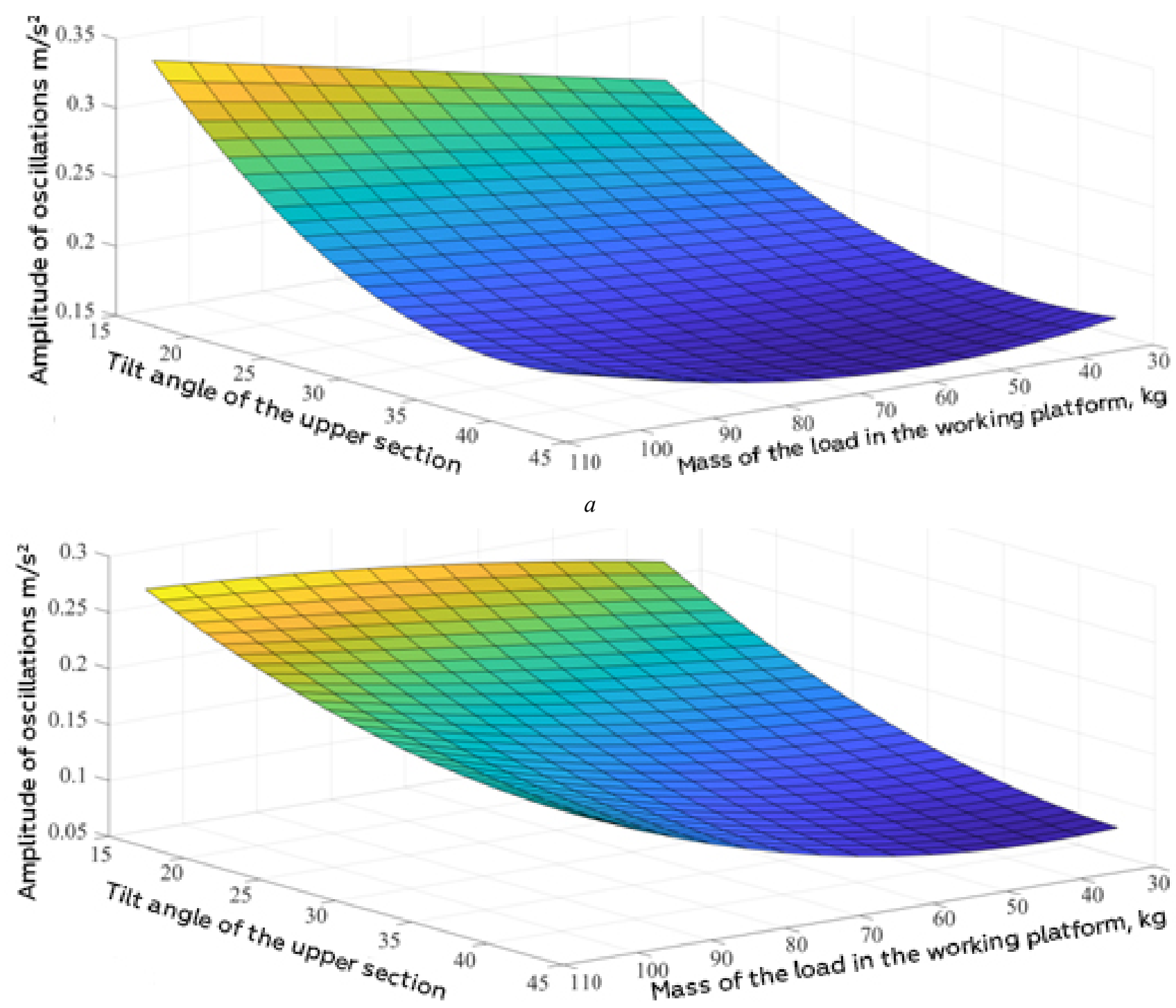

$b$

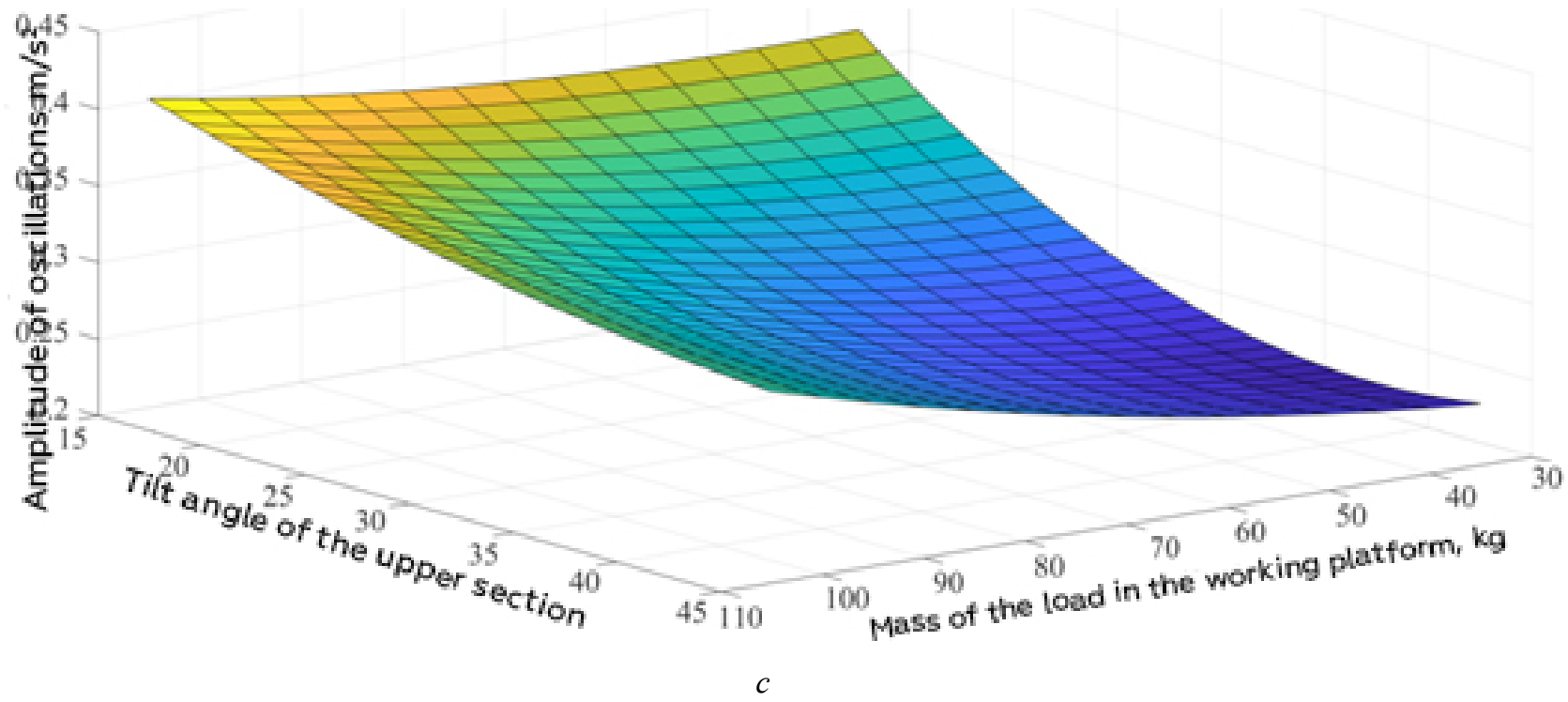

Figure 2. Response surface of the maximum amplitude of oscillations of the working platform from the angle of inclination of the upper sections of the boom and the mass of the load: a - at an angle of inclination of the lower section of the boom $15^{\circ} ; b$ - at an angle of inclination of the lower section of the boom $30^{\circ} ; c$ - at an angle of inclination of the lower section of the boom $45^{\circ}$. 


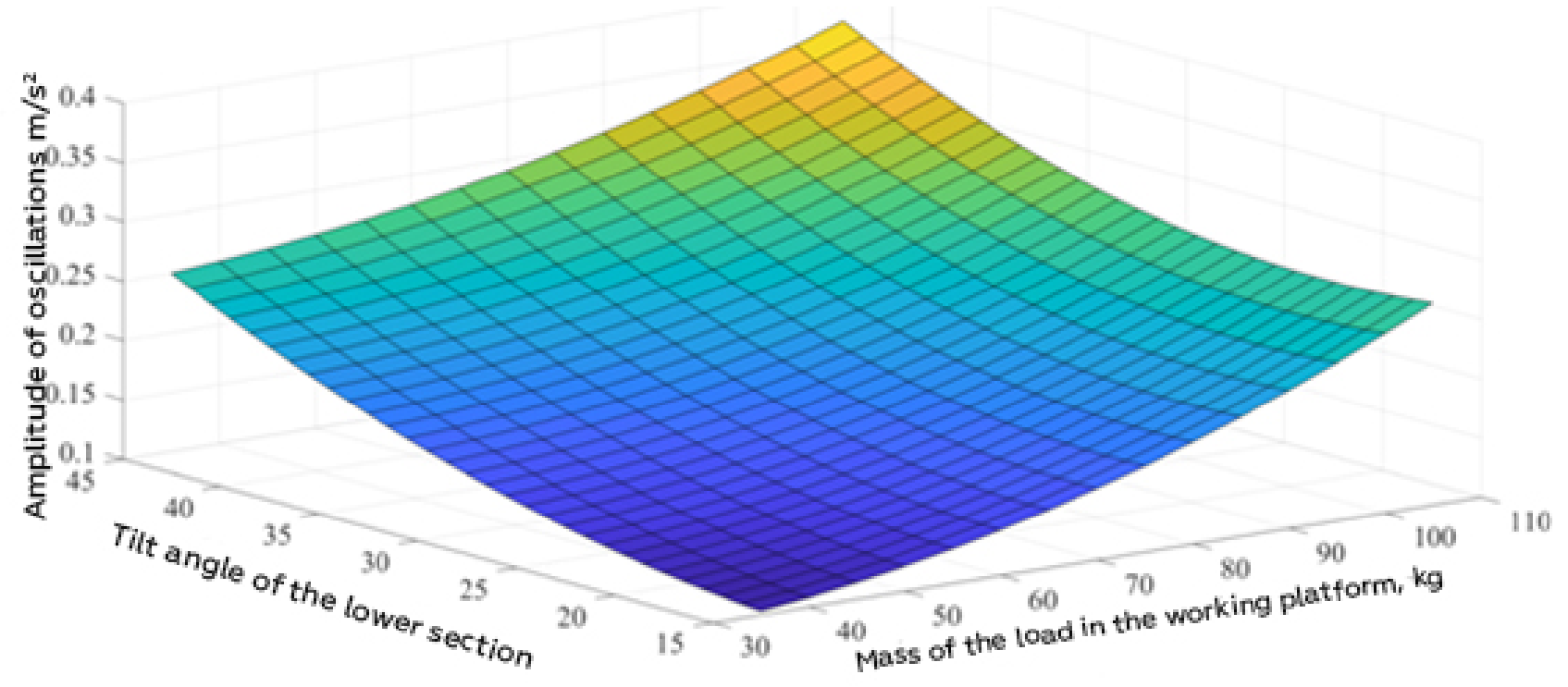

$a$
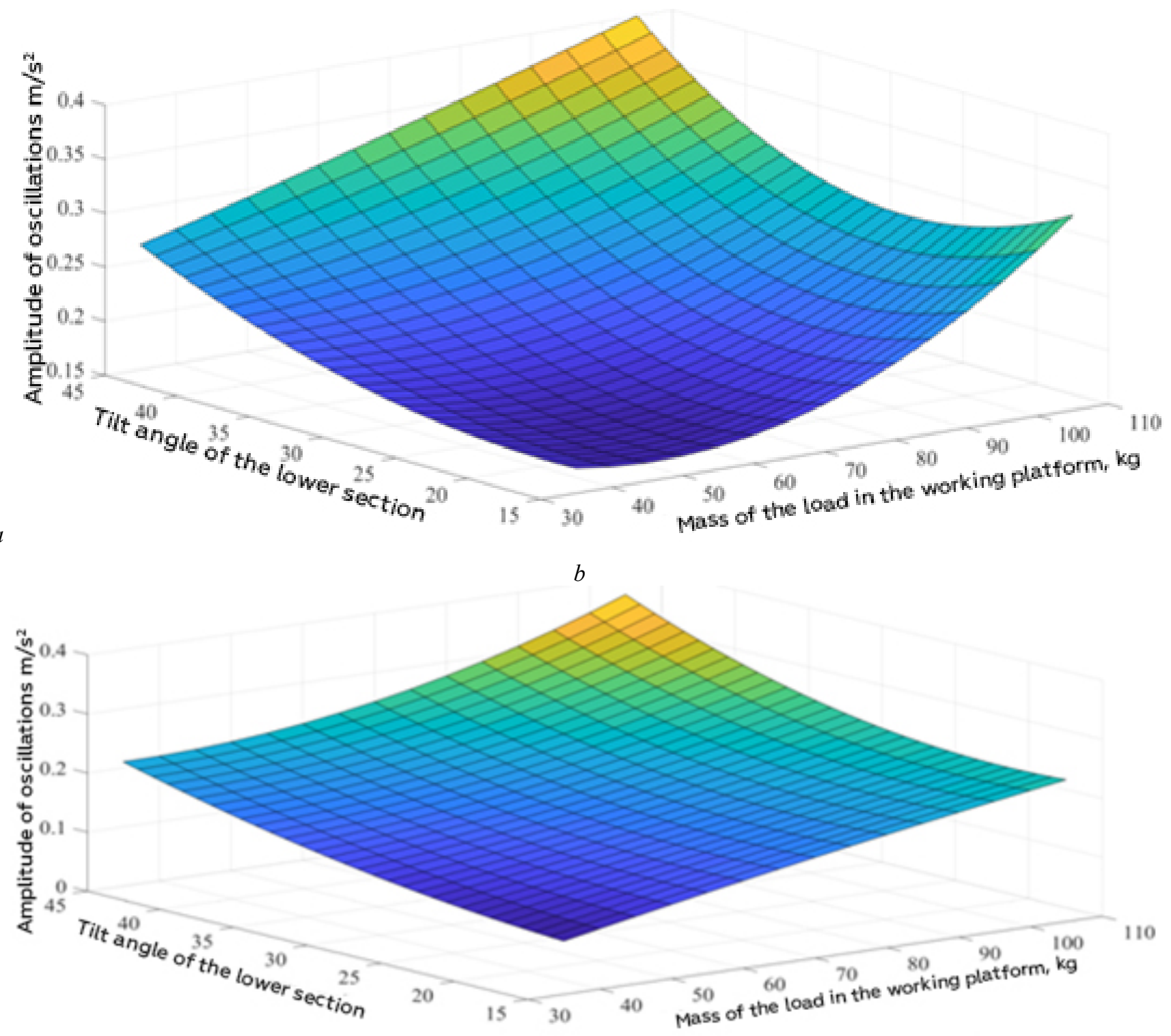

$c$

Figure 3. The surface of the response of the maximum amplitude of oscillations of the working platform from the angle of inclination of the lower sections of the boom and the weight of the load: a-at an angle of inclination of the upper section of the boom $15^{\circ} ; b$ - at an angle of inclination of the upper section of the boom $30^{\circ} ; c$-at an angle of inclination of the upper section of the boom $45^{\circ}$. 


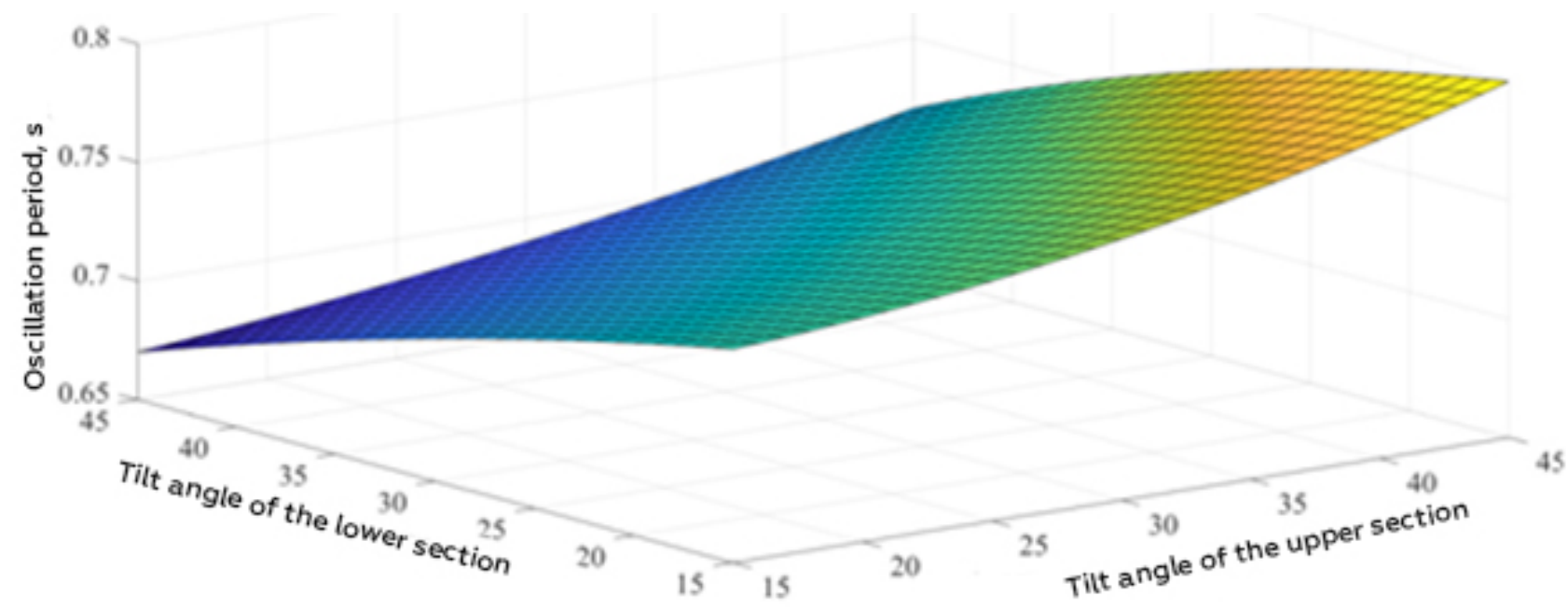

$a$

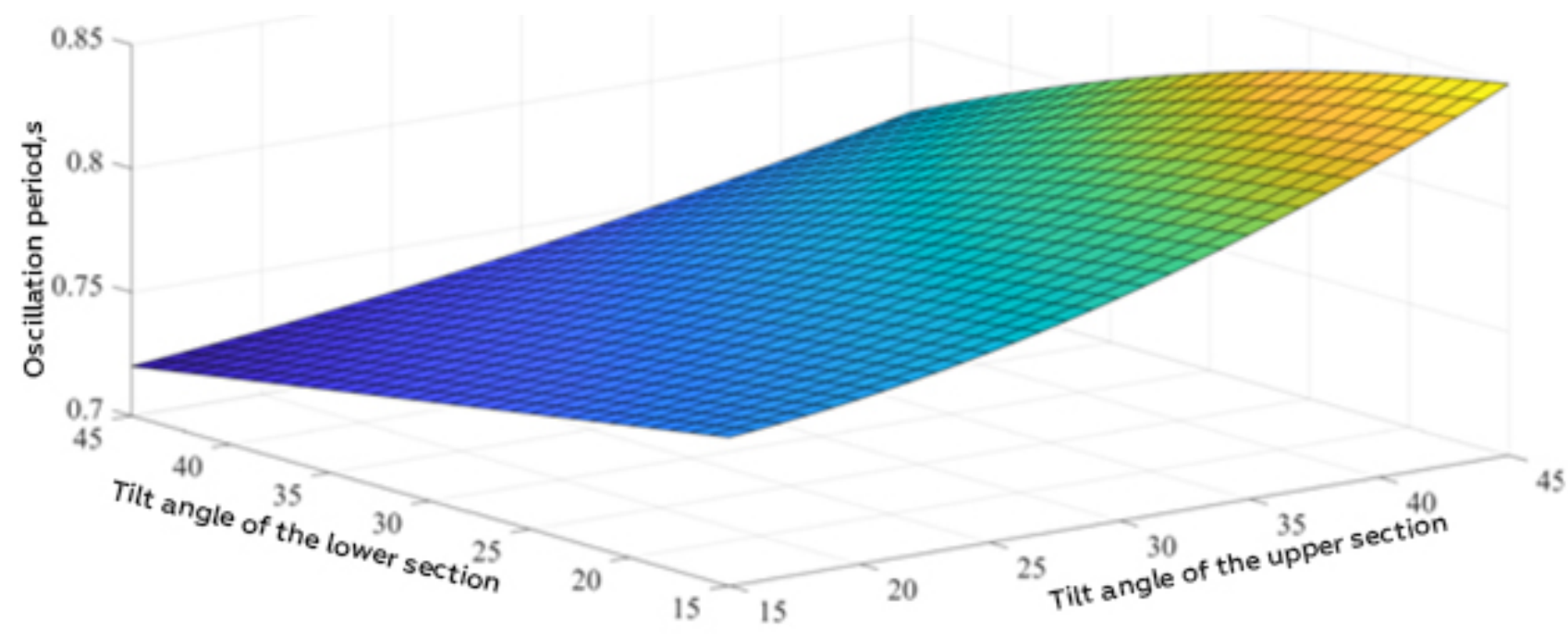

$b$

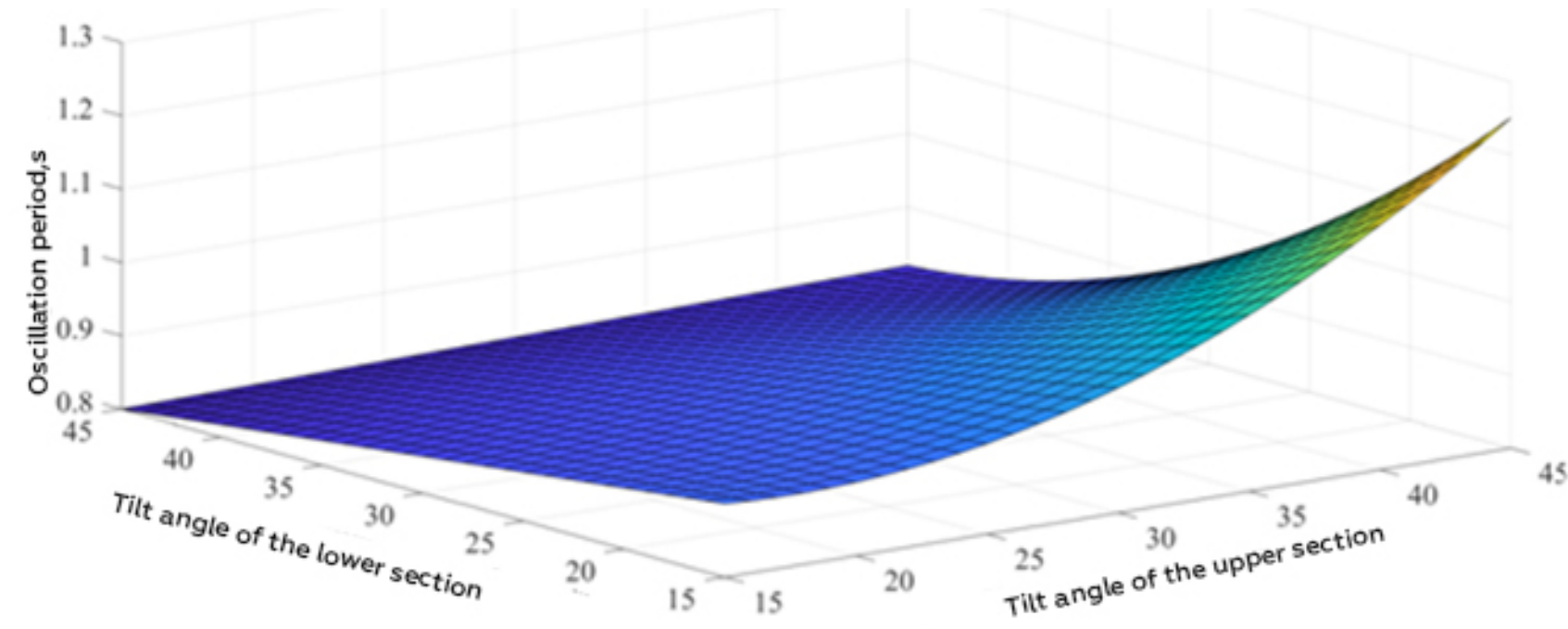

$c$

Figure 4. The surface of the response of the oscillation period of the working platform from the angles of inclination of the lower and upper sections of the boom: a - with a load mass of $35 \mathrm{~kg} \mathrm{~b}$ - with a load mass of $70 \mathrm{~kg} \mathrm{c}$ - with a load mass of $105 \mathrm{~kg}$. 

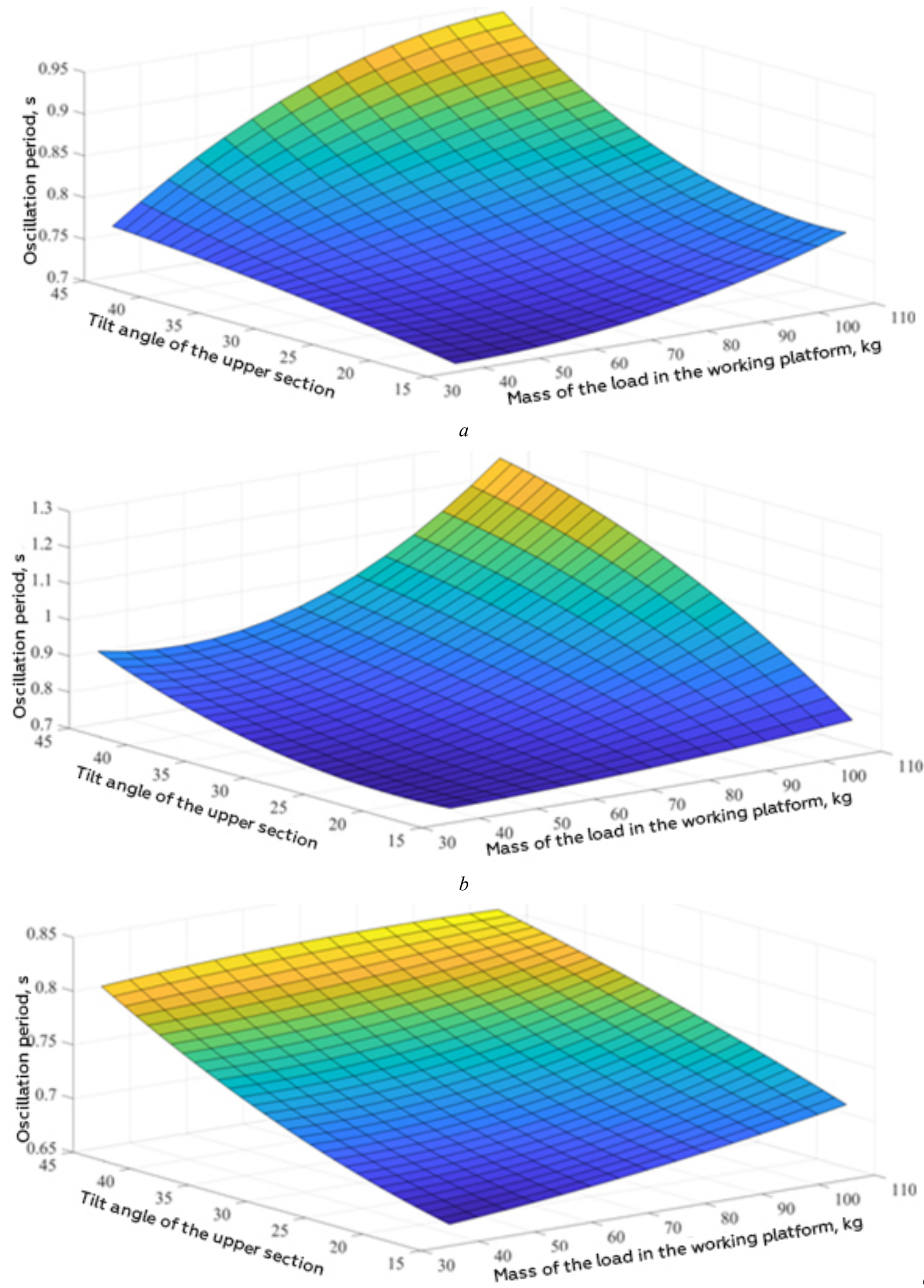

Figure 5. The surface of the response of the oscillation period of the working platform from the angle of inclination of the upper sections of the boom and the weight of the load: $a$-at an angle of inclination of the lower section of the boom $15{ }^{\circ} ; b$ - at an angle of inclination of the lower section of the boom $30^{\circ} ; c$ - at an angle of inclination of the lower section of the boom $45^{\circ}$. 


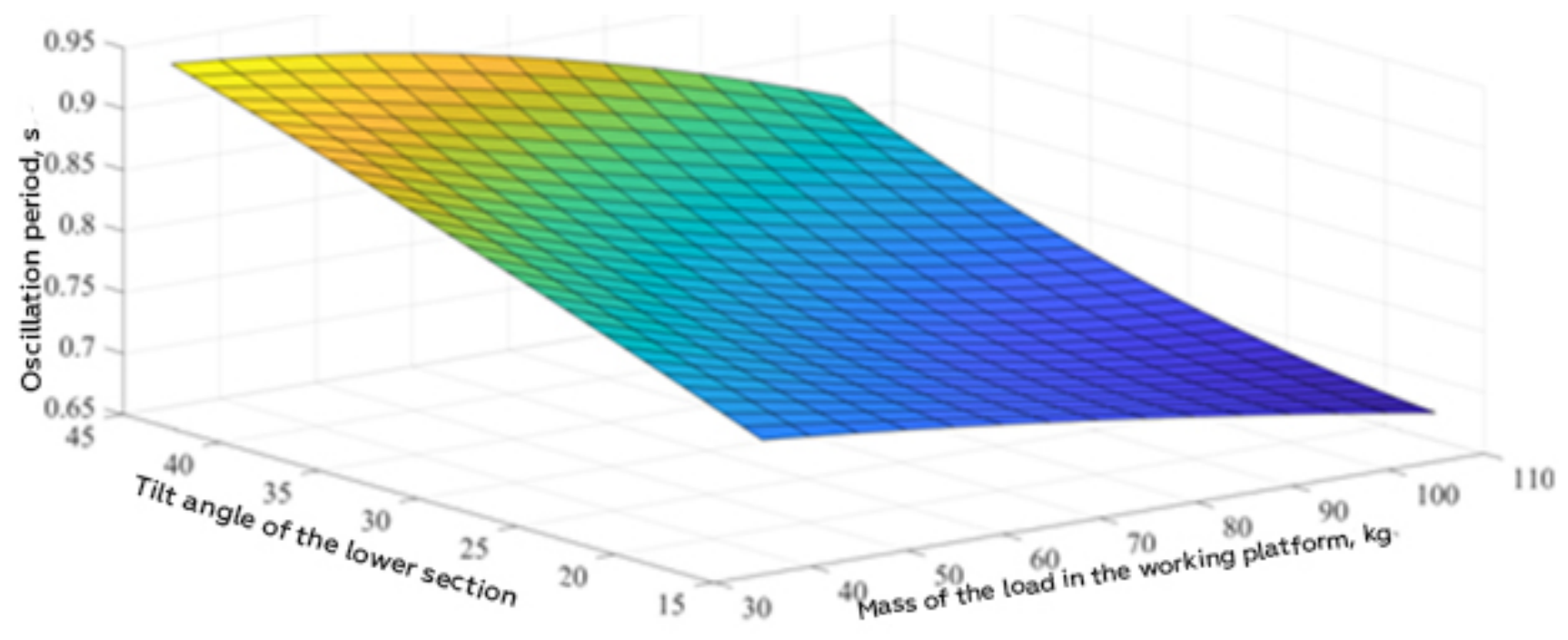

a

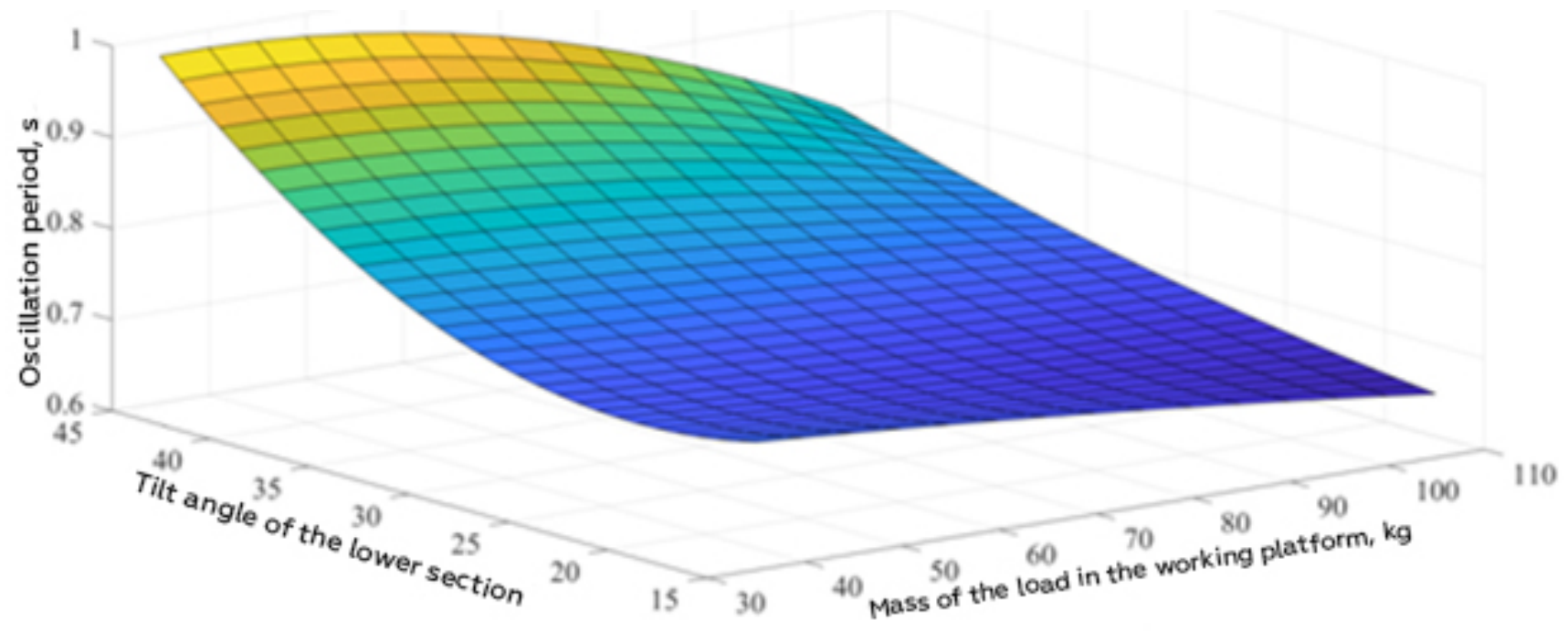

b

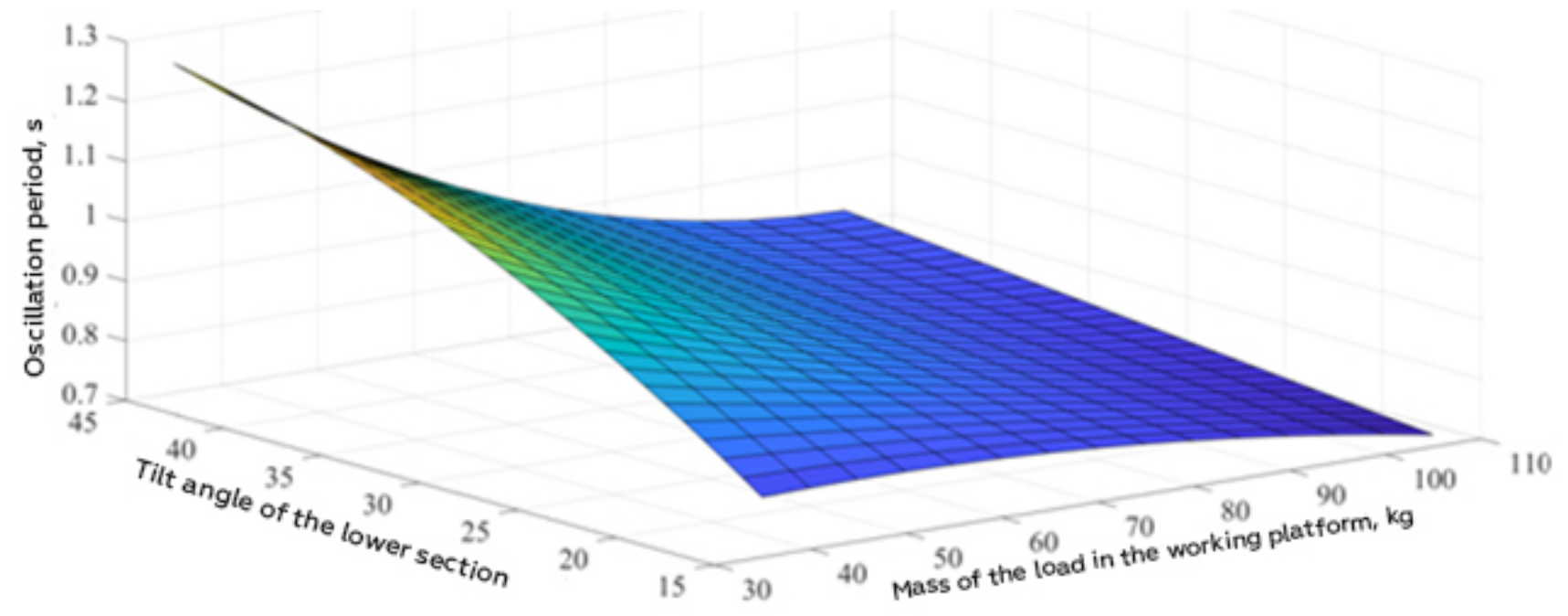

c

Figure 6. The surface of the response of the oscillation period of the working platform from the angle of inclination of the lower sections of the boom and the weight of the load: $a$ - at an angle of inclination of the upper section of the boom $15{ }^{\circ} ; b$ - at an angle of inclination of the upper section of the boom $30^{\circ} ; \mathrm{c}$ - at an angle of the upper lower section of the boom 45 


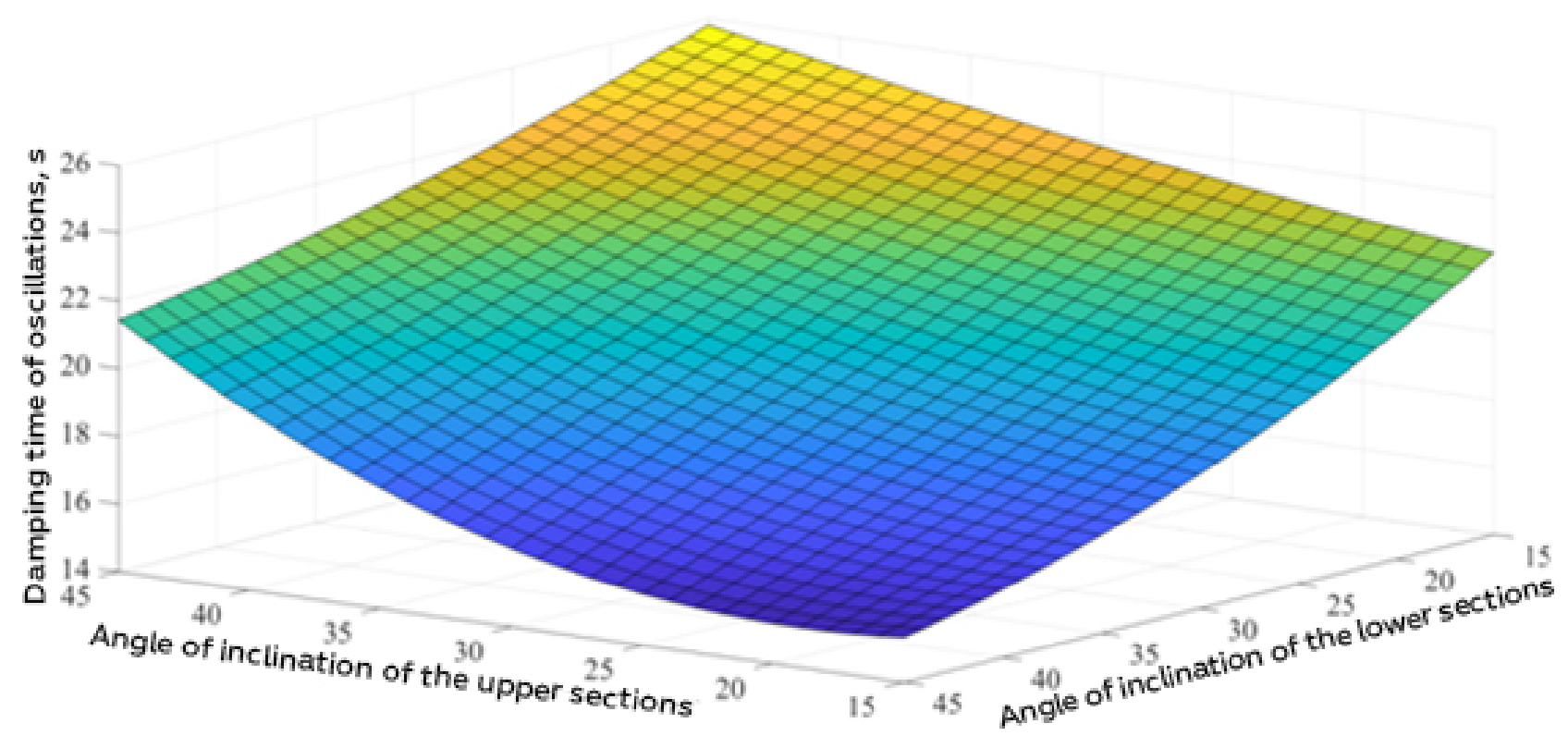

$a$
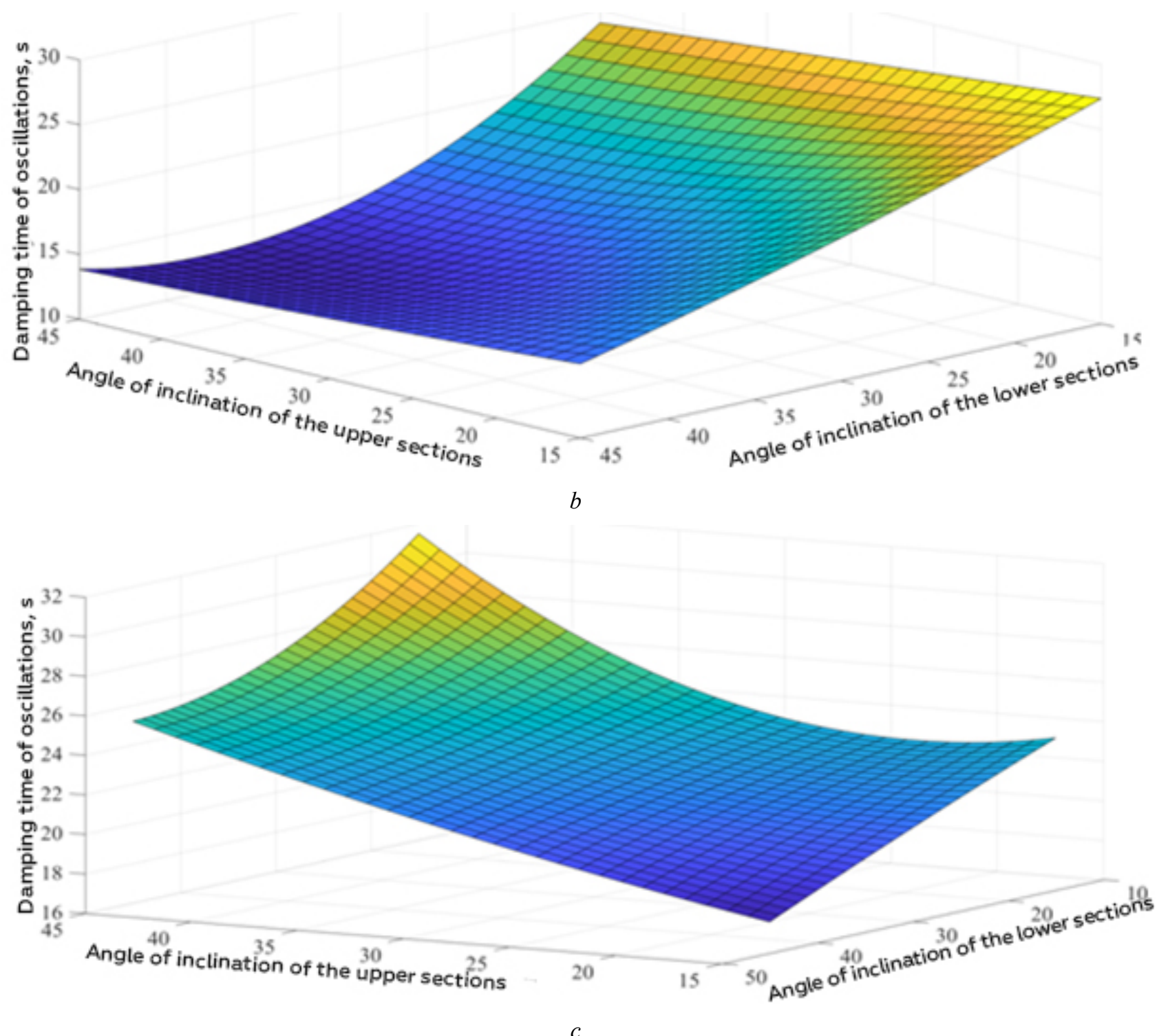

Figure 7. The surface of the response of the damping time of oscillations of the working platform from the angles of inclination of the lower and upper sections of the boom: a - with a load mass of $35 \mathrm{~kg} \mathrm{~b}$ - with a load mass of $70 \mathrm{~kg} \mathrm{c}$ - with a load mass of $105 \mathrm{~kg}$. 


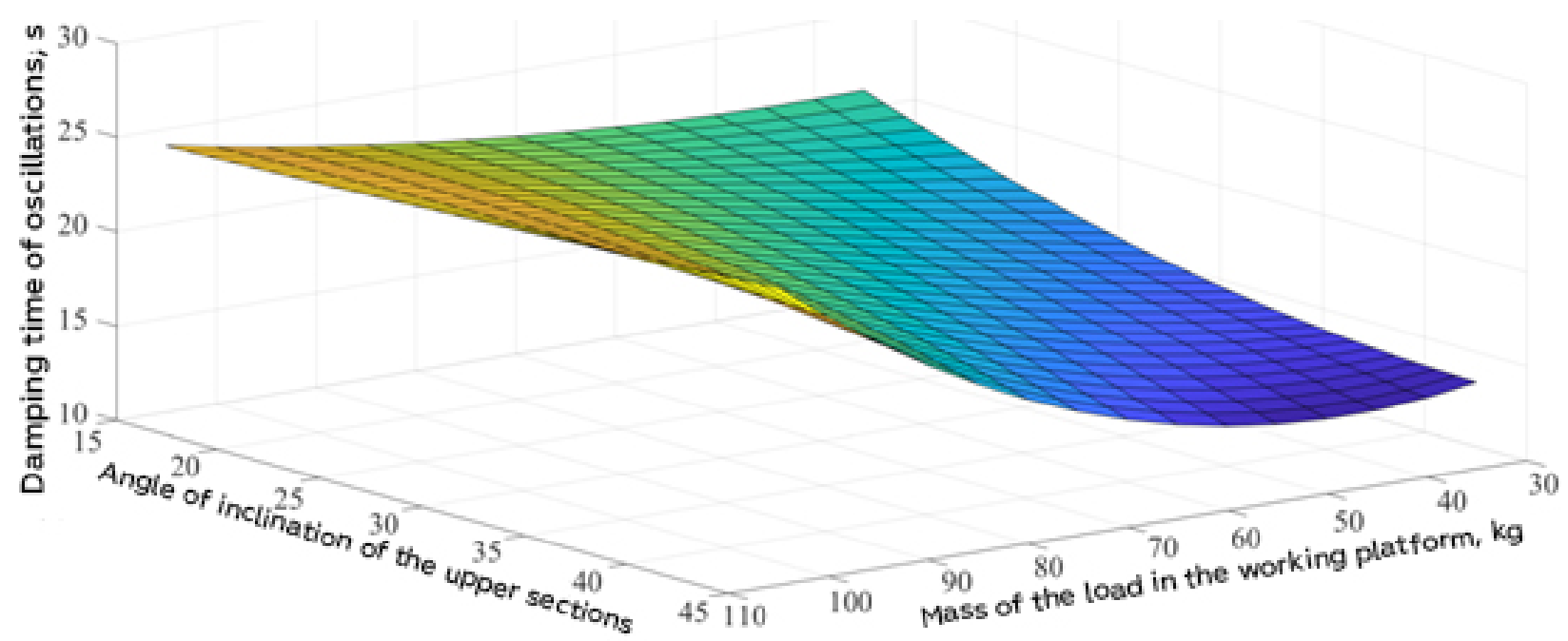

$a$
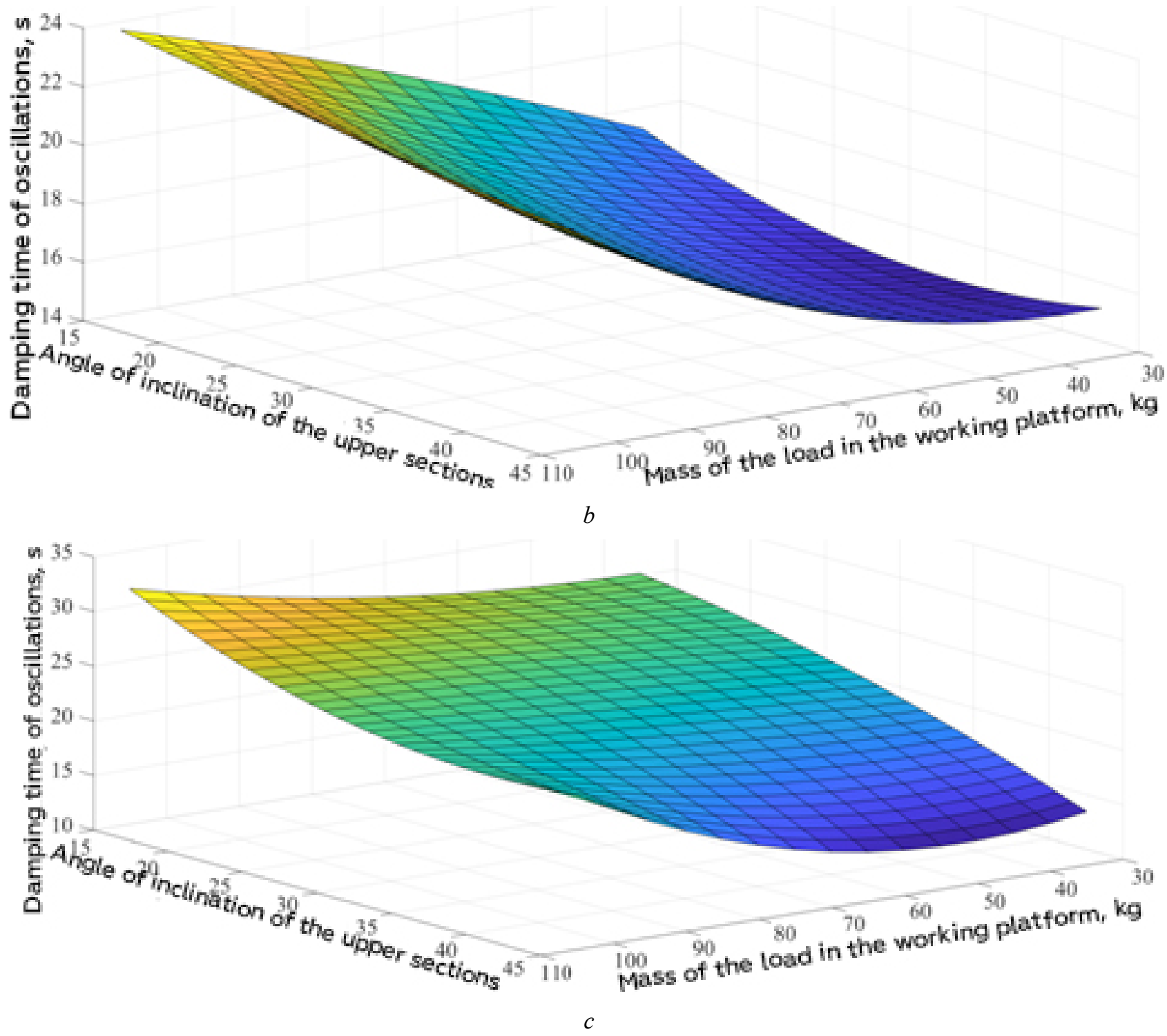

Figure. 8. Response surface of the damping time of oscillations of the working platform from the angle of inclination of the upper sections of the boom and the weight of the load: $a$ - at an angle of inclination of the lower section of the boom $15 \circ ; b$ - at an angle of inclination of the lower section of the boom $30^{\circ} ; \mathrm{c}$ - at an angle of inclination of the lower section of the boom $45^{\circ}$. 

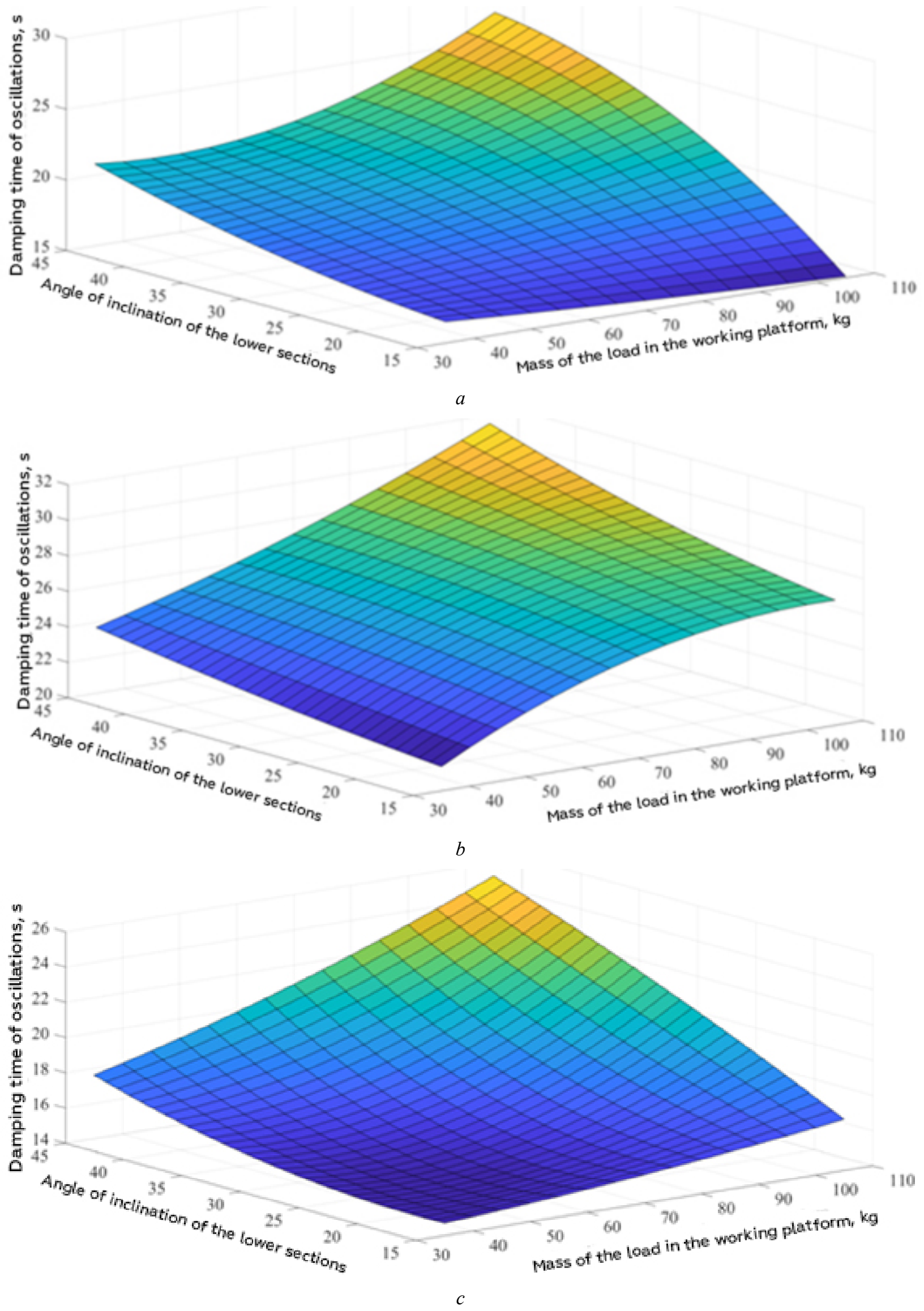

Figure 9. The surface of the response of the damping time of the oscillations of the working platform from the angle of inclination of the lower sections of the boom and the weight of the load: a - at an angle of inclination of the upper section of the boom $15^{\circ} ; b$ - at an angle of inclination of the upper section of the boom $30^{\circ}$; $c$ - at an angle of the upper lower section of the boom $45^{\circ}$ 
As a result of the analysis of the response surfaces of the maximum amplitude of acceleration oscillations when the working platform is locked, the period of oscillations and the time of their damping from the working mass and the angles of inclination of the lower and upper sections of the boom, it can be concluded that the value of the maximum amplitude of acceleration oscillations when the working platform is locked is most influenced by the weight of the load in the working platform. It should be noted that with a combination of factors such as the angle of inclination of the lower and upper sections of the boom (Fig. 1), the amplitude of oscillations of acceleration when the working platform is locked acquires maximum values at an angle of inclination of the lower section of the boom of $45^{\circ}$ and an angle of inclination of the upper section of the boom of $15^{\circ}$. With an increase in the mass of the load, the maximum amplitude of acceleration oscillations when the working platform is locked increases by $28 \%$ (from $0.29 \mathrm{~m} / \mathrm{s}^{2}$ with a load mass of $35 \mathrm{~kg}$ to $0.4 \mathrm{~m} / \mathrm{s}^{2}$ with a load mass of 105 $\mathrm{kg})$.

The response surface of the maximum amplitude of acceleration oscillations when the working platform is locked from the working mass and the angle of inclination of the upper section of the boom acquires maximum values with a weight of $105 \mathrm{~kg}$ and an angle of inclination of the upper section of the boom $15^{\circ}$ (Fig. 2). With an increase in the angle of inclination of the lower section of the boom, the maximum amplitude of acceleration oscillations when the working platform is locked increases by $35 \%$ (from $0.26 \mathrm{~m} / \mathrm{s} 2$ at an angle of inclination of the lower section of the boom $15^{\circ}$ to $0.4 \mathrm{~m} / \mathrm{s} 2$ at an angle of inclination of the lower section of the boom $45^{\circ}$ ).

With a combination of such factors as the working mass and the angle of inclination of the lower section of the boom, the response surface of the maximum amplitude of oscillations of acceleration when the working platform is locked (Fig. 3) acquires maximum values with a load mass of $105 \mathrm{~kg}$ and an angle of inclination of the lower section of the boom of $45^{\circ}$. At the same time, with a change in the angle of inclination of the upper section of the boom from $15^{\circ}$ to $45^{\circ}$, the maximum amplitude of oscillations of acceleration when locking the working platform decreases by $10 \%(0.4 \mathrm{~m} / \mathrm{s} 2$ at an angle of inclination of the upper section of the boom $15^{\circ}$ to $0.36 \mathrm{~m}$ / s2 at angle of inclination of the upper boom section $45^{\circ}$ ).

The period of oscillation of the working platform after stopping with a combination of factors such as the angle of inclination of the lower and upper sections of the boom (Fig. 4) acquires maximum values when the angle of the lower section of the boom is $15^{\circ}$ and the angle of inclination of the upper section of the boom is $45^{\circ}$. With an increase in the mass of the load in the working platform from $35 \mathrm{~kg}$ to $105 \mathrm{~kg}$, the oscillation period increases by $37 \%$ (from $0.79 \mathrm{~s}$ with a load mass of $35 \mathrm{~kg}$ to $1.25 \mathrm{~s}$ with a load mass of $105 \mathrm{~kg}$ ).

The response surface of the oscillation period of the working platform after locking from the working mass and the angle of inclination of the upper section of the boom acquires maximum values with a weight of $105 \mathrm{~kg}$ and an angle of inclination of the upper section of the boom $45^{\circ}$ (Fig. 5). With an increase in the angle of inclination of the lower section of the boom from $15^{\circ}$ to $45^{\circ}$, the period of oscillation of the working platform after locking decreases by $36 \%$ (from $1.25 \mathrm{~s}$ at an angle of inclination of the lower section of the boom $15^{\circ}$ to $0.8 \mathrm{~s}$ at an angle of inclination of the lower section of the boom $45^{\circ}$ ).

With a combination of factors such as the operating mass and the angle of inclination of the lower section of the boom, the response surface of the oscillation period of the working platform after locking (Fig. 6) acquires maximum values with a load weight of $35 \mathrm{~kg}$ and an angle of inclination of the lower section of the boom of $45^{\circ}$. At the same time, with a change in the angle of inclination of the upper section of the boom from $15^{\circ}$ to $45^{\circ}$, the period of oscillation of the working platform after locking increases by $22 \%(0.98 \mathrm{~s}$ at an angle of inclination of the upper section of the boom $15^{\circ}$ to $1.25 \mathrm{~s}$ at an angle of inclination of the upper section of the boom $45^{\circ}$ ).

The damping time of vibrations of the working platform after stopping with a combination of factors such as the angle of inclination of the lower and upper sections of the boom (Fig. 7) acquires maximum values at an angle of inclination of the lower section of the boom $15^{\circ}$ and an angle of inclination of the upper section of the boom $15^{\circ}$. With an increase in the weight of the load in the working platform from $35 \mathrm{~kg}$ to $105 \mathrm{~kg}$, the vibration damping time increases by $23 \%$ (from $24 \mathrm{~s}$ with a load weight of $35 \mathrm{~kg}$ to $31 \mathrm{~s}$ with a load weight of $105 \mathrm{~kg}$ ).

The response surface of the damping time of the oscillations of the working platform after stopping from the working mass and the angle of inclination of the upper section of the boom acquires maximum values with a weight of $105 \mathrm{~kg}$ and an angle of inclination of the upper section of the boom $15^{\circ}$ (Fig. 8). With an increase in the angle of inclination of the lower section of the boom from $15^{\circ}$ to $45^{\circ}$, the damping time of oscillations of the working platform after stopping increases by $25 \%$ (from $24 \mathrm{~s}$ at an angle of inclination of the lower section of the boom of $15^{\circ}$ to $31 \mathrm{~s}$ at an angle of inclination of the lower section of the boom of $45^{\circ}$ ).

With a combination of factors such as the operating mass and the angle of inclination of the lower section of the boom, the response surface of the damping time of oscillations of the working platform after locking (Fig. 9) takes on maximum values with a load mass of $105 \mathrm{~kg}$ and an angle of inclination of the lower section of the boom 45 $\circ$. At the same time, with a change in the angle of inclination of the upper section of the boom from $15^{\circ}$ to $45^{\circ}$, the damping time of oscillations of the working platform after locking is reduced by $19 \%$ (from $31 \mathrm{~s}$ at an angle of inclination of the upper section of the boom of 15 $\circ$ to $25 \mathrm{~s}$ at an angle of inclination of the upper section of the boom of $45^{\circ}$ )

\section{ACKNOWLEDGEMENTS}

According to the specified purpose and objectives of the study, the following conclusions can be drawn:

1. Statistical analysis of the results of the experimental study indicates that the operating parameters of the mobile lift significantly affect the indicators of oscillatory processes, such as the amplitude, period and damping time of oscillations occurring in the machine during operation.

2. Analysis of the response surfaces of the maximum amplitude, period and time of damping of 
oscillations of the working platform after it is locked from the operational indicators of the working process indicates that the highest indicators of oscillatory processes are observed when the working platform is lowered when the load mass and horizontal reach are maximum.

3. To prevent accidents that may arise during the locking of the MPP working platform, it is advisable to use a proportional hydraulic drive and a number of safety devices, which together will reduce the vibrations of the working platform, significantly increase the safety and ergonomics of the machine.

\section{REFERENCES}

[1] Shherbakov V.S. Avtomatizacziya modelirovaniya optimal'noj traektorii dvizheniya rabochego organa stroitel'nogo manipulyatora : monografiya / V.S. Shherbakov, I.A. Rebrova, M.S. Kory`tov. - Omsk : SibADI, 2009. - 106 s.

[2] Gurko A. G. Razrabotka sistemy` upravleniya dvizheniem avtogidropod emnika / A. G. Gurko, I. G. Kirichenko // Budi vnicztvo. Materi'aloznavstvo. Mashinobuduvannya. Seri'ya : Pi'djomno-transportni', budi`vel'ni' i' dorozhni' mashini i' obladnannya. 2014. - S. 210-220.

[3] Matematicheskoe modelirovanie proczessov v sisteme gidroprivoda lesny'kh manipulyatorov / [P.I. Popikov, P.I. Titov, A.A. Sidorov i dr.] // Nauchny j zhurnal KubGAU. - 2011. - \# 69(5) - S. 1-11.

[4] Ob`yomny`j gidroprivod v mobil’ny'kh podyomnikakh $\mathrm{s}$ rabochimi platformami : monografiya / [I.G. Kirichenko, G.A. Avrunin, V.B. Samorodov i dr.]. - Khar'kov : KhNADU, 2018. - 295 S.

[5] Barkov A.Yu. Rezhimy` nagruzheniya stroitel `ny`kh gruzopassazhirskikh pod'emnikov. Interstrojmekh2001 / A.Yu. Barkov, M.A. Stepanov // Trudy Mezhdunarodnoj nauchno-tekhnicheskoj konferenczii. - Sankt-Peterburg : Izdatel'stvo SPbGTU, 2001g. - S. 14-18.

[6] Barkov A.Yu. Analiz rezhimov nagruzheniya privodov stroitel`ny`kh pod`emnikov. Interstrojmekh-2002 / A.Yu. Barkov, M.A. Stepanov // Materialy' Mezhdunarodnoj nauchno-tekhnicheskoj konferenczii., Mogilev : Izdatel`stvo MGTU, 2002g. - S.391-394.
[7] Gurko O. G. Dosli dzhennya parametri`v rukhu avtogi dropi di jmacha $\mathrm{z} \quad$ obertal'nimi zchlenuvannyami / O. G. Gurko, Yu. O. Dolya // Novi' materi`ali i' tekhnologi'yi $\mathrm{v}$ metalurgi yi ta mashinobuduvanni`. - 2016. - \#2. - S. 121-127.

\section{Eksperimentalno proučavanje uticaja kombinacije radnih parametara pokretnog lifta na oscilatorne procese koji se javljaju nakon zaključavanja radne platforme}

Igor Kiričenko $^{1 *}$, Oleksandr Reznikov ${ }^{1}$, Dmitro Klec ${ }^{1}$, Anton Holodov 1

${ }^{1}$ Mašinski fakultet, Harkovski nacionalni univerzitet za automobile i puteve, Harkov (Ukrajina)

U radu je data detaljna analiza uticaja kombinacije indikatora performansi mobilnih liftova sa radnim platformama (MLVP) u fazi zaustavljanja $i$ procesa prigušenja vibracija nakon zaustavljanja radne platforme. $\mathrm{Na}$ osnovu rezultata eksperimentalnog istraživanja $i$ obrade dobijenih podataka urađena je analiza uticaja uglova nagiba gornjeg $i$ donjeg preseka strele $i$ mase tereta u radnoj platformi na maksimalnu amplitudu oscilacija ubrzanja kada je radna platforma zaključana, period oscilacija $i$ vreme njihovog prigušenja. Kao rezultat analize, spektar odzivnih površina maksimalne amplitude oscilacija ubrzanja kada je radna platforma zaključana, period oscilacija i vreme njihovog prigušenja od radne mase i uglovi nagiba donjeg i dobijeni su gornji preseci strele, na osnovu čega se može zaključiti da na vrednost maksimalne amplitude oscilacija ubrzanja $u$ vremenu zaključavanja radne platforme najviše utiče masa tereta $u$ radnoj platformi.

Ključne reči: Pokretni lift, Radna platforma, zaključavanje, Vibracije, Operativne performanse, Odzivna površina. 